\title{
FACTORS AFFECTING SMALL RUMINANT HOLDINGS WITHIN THE CROP-LIVESTOCK FARMING SYSTEM IN SOHAG GOVERNORATE, EGYPT
}

\author{
Salah Galal ${ }^{1}$, A. Elnahas ${ }^{2}$, E. Mousa ${ }^{3 *}$, M.A. Elshennawy ${ }^{4}$ and S.M. \\ Alsheikh $^{5}$ \\ 1- Department of Animal Production, Faculty of Agriculture, University of Ain Sham, \\ 2- Department of Animal Production, Faculty of Agriculture, University of Sohag, 3- \\ Department of Animal Production, Faculty of Agriculture, University of Assiut, 4 - \\ Sustainable Development Department, Environmental Studies \& Research Institute, \\ Sadat Branch, Menofia University 5- Animal and Poultry Breeding Department, \\ Desert Research Center, Cairo, Egypt, * Qassim University, KSA
}

\section{SUMMARY}

In 2004-2005 data were collected on 420 farmers (35 farmers from four villages within Jirjah, Dohag and Akhmim districts) selected at random from eleven districts in Sohag governorate. Average sheep and goat number per household in the districts studied was 15.1 and 5.7 heads, respectively. Among the factors affecting sheep and goat production, family size and village within district had significant effect on number of sheep. Similarly, district had significant effect on all gender-age classes of sheep and goats except males less than one year and more than two years in sheep and male more than two years in goats. Significant relationships were observed between number of buffaloes and berseem (Egyptian clover) area; crossbred cattle and darawa area; and sheep and animal units and family size. As family size increased by one member animal unit increased by 0.11 , most of these increases were from sheep, which is most responsive in meeting family needs. Stepwise analysis show only buffaloes and $A U$ had an $R^{2}$ of $>0.40$.

Keywords: Small holder, production system, South-Egypt, sheep and goat, age structure

\section{INTRODUCTION}

In 2009, the small ruminant population of 5.5 million sheep and 4.5 million goats in Egypt (FAOSTAT, 2011) was raised by nearly six million families (Galal et al., 2005). While the contribution of the two species to the national red meat production is only $12 \%$, they are quite important in social festivities and as a means for poverty alleviation among the landless and small holders. The great majority of small ruminants are kept under crop-livestock production system with holdings ranging from 1 to 5 heads per household at the national level. While small ruminants are quite adaptable to a diverse range of environmental and socioeconomic conditions the distribution of both species in Egypt differs somewhat from one ecosystem to another. In 2006, the percentage of sheep in north, mid and south Nile valley and outside the Nile valley in 2006 was 38, 19, 27 and 16, respectively, and for goats was

Issued by The Egyptian Society of Animal Production 
30, 24, 31 and 15, respectively, (Central Agricultural Statistics Administration, 2007), i.e. goats are more relatively common in the south. Nile Egypt encompasses the governorates Aswan, Sohag, Qena, Red Sea and Luxor City. Agriculture is the basic economic activity Sohag governoate where cultivated areas cover 315.5 thousand feddans ( 1 feddan $=4200 \mathrm{sq} \mathrm{m}$ ) (ICLDU, 2006). In Egypt, majority of research work on improvement of sheep and goat production and other livestock has been carried out under controlled conditions in experimental farms. Information greatly lacking at the grass-root level includes factors impacting on production. The objective of the present work was an attempt to identify factors affecting aspects of sheep and goat production under the crop-livestock farming system in Sohag governorate of southern Egypt.

\section{MATERIALS AND METHODS}

\section{General:}

Sohag governorate, in the middle of South Egypt between 26o 33" N latitudes and 310 42" E longitudes, comprises eight districts on the western side of the River Nile and three districts on the eastern side. Three districts, Jirjah, Sohag (in the western side of the River Nile) and Akhmim (in the eastern side of the River Nile), four villages within each districts, 35 farmers within each village were all randomly chosen for this study (total number of farmers $=420$ ).

Data were collected during 13 months from August 2004 to September 2005 through a field survey using structured questionnaire covering general information on village; socio-economic status of the farmer and his family; family members' contribution to cultivation and animal production activities; farm size and main field crops; flock and herd size for different livestock species; and management systems of small ruminants.

Variables included were area cultivated with wheat (Triticum Sp.), berseem (Trifolium alexandrinum) and faba bean (Vicia faba) as winter crops and maize (Zea mays), sorghum (Sorghum bicolor), millet (Pennisetum typhoides) and darawa (fodder maize) (Zea mays) as summer crops. Livestock variables were number each of local cattle, crossbred cattle, buffalo, sheep, goats and animal units, AU (according to Barnard and Nix, 1993). Average land holding was 1.68 feddan, livestock holding 4.65 $\mathrm{AU}$ where the highest species contribution to AU was, sheep followed by buffalo, then goat, local cattle and crossbred cattle. Average family size was 5.82 . Alsheikh et al. (2011) provide more details on resources.

\section{Statistical analysis:}

The mathematical model for the analyses of number of animals (buffalo, local cattle, crossbred cattle, sheep, goats and AU) included fixed affects of districts; villages within district and the following co-variables: farm size, berseem, wheat, faba bean, maize, sorghum, millet, darawa and family size Data were analyzed using SAS ver 6.12 (1989) according to the following model:

$$
\mathrm{Y}_{\mathrm{ijk}}=\alpha+\mathrm{D}_{\mathrm{i}}+\mathrm{V}(\mathrm{D})_{\mathrm{ij}}+\mathrm{F}(\mathrm{V}(\mathrm{D}))_{\mathrm{ijk}}+\sum_{i=1}^{9} \mathrm{~B}_{\mathrm{l}} \mathrm{X}_{\mathrm{lijk}} \ldots \ldots \ldots \text {.... }
$$


$Y_{\mathrm{ijk}}=$ an observation of the studied traits (number of each of buffaloes, local cattle, crossbred cattle, sheep, goats and AU) in the $\mathrm{k}^{\text {th }}$ farm within

$\alpha=$ intercept; the $\mathrm{j}^{\text {th }}$ village within the $\mathrm{i}^{\text {th }}$ district;

$D_{i=}$ the effect of the $i^{\text {th }}$ district, $i=1,2,3$;

$\mathrm{Vi}_{\mathrm{j}}=$ the effect of the $\mathrm{j}^{\mathrm{th}}$ village within district, $\mathrm{j}=1,2,3,4$;

$B_{1}=$ partial regression of $Y$ on the $X\left(\right.$ area is in feddan, 1 feddan $=4200 \mathrm{~m}^{2}$ ) where

$\mathrm{X}_{1}=$ farm size;

$\mathrm{X}_{2}=$ berseem area;

$\mathrm{X}_{3}=$ wheat area;

$\mathrm{X}_{4}=$ faba bean area;

$\mathrm{X}_{5}=$ maize area;

$\mathrm{X}_{6}=$ sorghum area;

$\mathrm{X}_{7}=$ millet area;

$\mathrm{X}_{8}=$ darawa area; and

$\mathrm{X}_{9}=$ family size; and

$\mathrm{F}_{\mathrm{ijk}}=$ the effect of $\mathrm{k}^{\text {th }}$ farmer within $\mathrm{j}^{\text {th }}$ village within $\mathrm{i}^{\text {th }}$ district, $\mathrm{k}=1, \ldots 35$.

An alternate model was used to study the fixed effects of districts, village within districts, farmers within village within districts on age-gender-species classes.

$$
\mathrm{Y}_{\mathrm{ijk}}=\mu+\mathrm{D}_{\mathrm{i}}+\mathrm{V}(\mathrm{D})_{\mathrm{ij}}+\mathrm{F}(\mathrm{V}(\mathrm{D}))_{\mathrm{ijk}} \ldots \ldots \ldots \text {. Model } 2
$$

where, $Y_{\mathrm{ijk}}=$ an observation of studied traits in the $\mathrm{k}^{\text {th }}$ farm within the $\mathrm{j}^{\text {th }}$ village within the $i^{\text {th }}$ district of number of animals at different ages (males less than one year $(\mathrm{M}<1 \mathrm{yr})$, females less than one year $(\mathrm{F}<1 \mathrm{yr})$, males between 1 to 2 years $\mathrm{M}(1-2) \mathrm{yr}$, females between 1 to 2 years $F(1-2) y r$, males older than 2 years $(M>2 y r)$, female older than 2 years $(F>2$ yr) and animal units (AU) for different studied species. Other effects are defined as in Model 1. The residuals of dependent variables in the mathematical model were regressed on all studied variables $\left(\mathrm{X}_{1}\right.$ to $\mathrm{X}_{9}$ defined under Model 2) in a forward stepwise regression analysis, and only those regression coefficients that are significant were included.

\section{RESULTS AND DISCUSSION}

\section{Factors affecting livestock numbers:}

Number of livestock per household varied significantly among districts in all species except sheep (Table 1). The most pronounced differences in species/genotype composition in large ruminants, were in Akhmim across the river from the urban Sohag with no crossbred cattle but with the largest number of buffalos as a peri-urban supplier of milk. Akhmim and Sohag districts with the highest number of sheep and goats per household provide Sohag with meat. Jirjah is considered a hinter land of Sohag city (Fig. 1). The average numbers of sheep and goats per household (15.13 and 5.72, respectively, Table 2) are quite high compared to the national figures of 3.3 and 3.0, respectively (Ministry of Agriculture and Land Reclamation (Egypt) and FAO, 2003) but it has long been stated that the intensity of small ruminants is higher in South Egypt than elsewhere in the country. 
Table 1. Means of livestock numbers per household in Sohag governorate

\begin{tabular}{|c|c|c|c|c|c|c|c|c|}
\hline \multicolumn{2}{|l|}{ Source } & $\begin{array}{l}\text { Sample } \\
\text { size }\end{array}$ & Buffalo & L-cattle & C-cattle & Sheep & Goats & $\mathrm{AU}$ \\
\hline \multicolumn{2}{|l|}{ Mean } & 420 & 0.88 & 0.42 & 0.13 & 15.13 & 5.72 & 4.40 \\
\hline \multicolumn{2}{|c|}{ Districts } & & $* *$ & $*$ & $* *$ & ns & $* *$ & $* *$ \\
\hline \multicolumn{2}{|c|}{ Akhmim } & 140 & $1.00^{\mathrm{a}}$ & $0.44^{\mathrm{a}}$ & $0.00^{\mathrm{a}}$ & $16.95^{\mathrm{a}}$ & $6.87^{\mathrm{a}}$ & $4.83^{\mathrm{a}}$ \\
\hline \multicolumn{2}{|c|}{ Jirjah } & 140 & $0.83^{\mathrm{a}}$ & $0.43^{\mathrm{a}}$ & $0.24^{\mathrm{b}}$ & $13.13^{\mathrm{b}}$ & $4.35^{\mathrm{b}}$ & $3.97^{\mathrm{b}}$ \\
\hline \multicolumn{2}{|l|}{ Sohag } & 140 & $0.80^{\mathrm{a}}$ & $0.40^{\mathrm{a}}$ & $0.16^{\mathrm{b}}$ & $15.30^{\mathrm{a}}$ & $5.95^{\mathrm{a}}$ & $4.39^{c}$ \\
\hline \multicolumn{3}{|c|}{ Villages within district } & ns & ns & ns & $* *$ & ns & $* *$ \\
\hline \multicolumn{2}{|c|}{ Akhmim:1 } & 35 & $1.03 \mathrm{a}$ & $0.43 \mathrm{a}$ & $0.00 \mathrm{a}$ & $11.85 \mathrm{a}$ & $5.65 \mathrm{a}$ & $3.94 \mathrm{a}$ \\
\hline & 2 & 35 & $0.88 \mathrm{a}$ & $0.54 \mathrm{a}$ & $0.00 \mathrm{a}$ & $17.00 \mathrm{a}$ & $9.14 \mathrm{a}$ & $5.03 \mathrm{~b}$ \\
\hline & 3 & 35 & $1.08 \mathrm{a}$ & $0.51 \mathrm{a}$ & $0.00 \mathrm{a}$ & $18.34 b$ & $5.34 \mathrm{a}$ & $5.00 \mathrm{~b}$ \\
\hline & 4 & 35 & $1.00 \mathrm{a}$ & $0.28 \mathrm{a}$ & $0.00 \mathrm{a}$ & $20.62 b$ & $7.34 \mathrm{a}$ & $5.34 \mathrm{~b}$ \\
\hline Jirjah: & 1 & 35 & $0.80 \mathrm{a}$ & $0.46 a$ & $0.08 \mathrm{a}$ & $12.34 \mathrm{a}$ & $4.77 \mathrm{a}$ & $3.85 \mathrm{ab}$ \\
\hline & 2 & 35 & $0.71 \mathrm{a}$ & $0.26 \mathrm{a}$ & $0.17 \mathrm{a}$ & $12.11 \mathrm{a}$ & $4.02 \mathrm{a}$ & $3.50 \mathrm{a}$ \\
\hline & 3 & 35 & $0.91 \mathrm{a}$ & $0.40 \mathrm{a}$ & $0.31 \mathrm{a}$ & $13.48 \mathrm{a}$ & $4.22 \mathrm{a}$ & $4.06 \mathrm{~b}$ \\
\hline & 4 & 35 & $0.88 \mathrm{a}$ & $0.60 \mathrm{a}$ & $0.37 \mathrm{a}$ & $14.60 \mathrm{a}$ & $4.37 \mathrm{a}$ & $4.48 b$ \\
\hline Sohag: & 1 & 35 & $0.83 \mathrm{a}$ & $0.28 \mathrm{a}$ & $0.20 \mathrm{a}$ & $15.17 \mathrm{a}$ & $4.94 \mathrm{a}$ & $4.30 \mathrm{a}$ \\
\hline & 2 & 35 & $0.88 \mathrm{a}$ & $0.40 \mathrm{a}$ & $0.26 \mathrm{a}$ & $19.00 \mathrm{a}$ & $6.54 \mathrm{a}$ & $5.24 b$ \\
\hline & 3 & 35 & $0.94 a$ & $0.51 \mathrm{a}$ & $0.20 \mathrm{a}$ & $11.57 \mathrm{a}$ & $5.28 \mathrm{a}$ & $4.02 \mathrm{a}$ \\
\hline & 4 & 35 & $0.54 \mathrm{a}$ & $0.28 \mathrm{a}$ & $0.00 \mathrm{a}$ & $15.45 \mathrm{a}$ & $7.02 \mathrm{a}$ & $4.00 \mathrm{a}$ \\
\hline
\end{tabular}

As for the relationship between livestock numbers and covariates studied; buffalo numbers and berseem area; crossbred cattle and darawa area; sheep and family size; and animal units and family size (Table 2) were significant. These regressions indicate that berseem is the main source of feed for buffalo in winter in the governorate, and as family increases farmers try to keep more 0.64 of sheep to meet their own needs. Farmers with crossbred cattle must ensure a good source of feed during summer by growing the green fodder darawa. As family size increases by one member AU increases significantly by 0.11 , where most of this increase is derived from sheep, i.e. sheep were the most responsive species to meet the family needs. Sheep contribute about 59\%, 57\% and 59\% to AU in Akhmim, Jirjah and Sohag, respectively. While, goats contribute about $24 \%, 18 \%$ and $23 \%$ of AU in the three districts, respectively.

Factors Affecting Number of Small Ruminants within Different Ages:

Structures for the flocks and herds in the three districts are presented in Table 3. Number of reproducing females $(>2)$ was higher in sheep than goats but weanlings $(<1 \mathrm{yr})$ were higher in goats reflecting the higher twinning rate of the latter. Breeding 
males in both species were $6 \%$. Generally age structures in the three districts are similar for each species.

Table 2. Partial regression coefficients for number of different livestock per household on cropping pattern (area, fadden) and family size

\begin{tabular}{lcccccc}
\hline Source & Buffalo & L- cattle & C- cattle & Sheep & Goats & AU \\
\hline Farm size & $0.10 \pm$ & $0.05 \pm$ & 0.02 & $-2.11 \pm$ & $1.24 \pm$ & $0.02 \pm$ \\
& 0.262 & 0.273 & \pm 0.207 & 3.09 & 1.73 & 0.439 \\
Berseem & $1.13^{*} \pm$ & $0.19 \pm$ & $-0.29 \pm$ & $4.81 \pm$ & $-4.55 \pm$ & $1.23 \pm$ \\
& 0.456 & 0.412 & 0.361 & 5.38 & 3.00 & 0.764 \\
Wheat & $0.39 \pm$ & $-0.66 \pm$ & $-0.43 \pm$ & $1.13 \pm$ & $-2.38 \pm$ & $-0.78 \pm$ \\
& 0.38 & 0.395 & 0.346 & 5.16 & 2.88 & 0.733 \\
Faba & $0.16 \pm$ & $-0.65 \pm$ & $-0.18 \pm$ & $0.49 \pm$ & $-0.98 \pm$ & $-0.74 \pm$ \\
bean & 0.418 & 0.378 & 0.331 & 4.93 & 2.75 & 0.701 \\
Sorghum & $-0.29 \pm$ & $0.74 \pm$ & $0.48 \pm$ & $-0.88 \pm$ & $1.32 \pm$ & $0.74 \pm$ \\
& 0.465 & 0.420 & 0.368 & 5.49 & 3.06 & 0.779 \\
Maize & $-0.29 \pm$ & $0.56 \pm$ & $0.42 \pm$ & $0.65 \pm$ & $0.98 \pm$ & $0.81 \pm$ \\
& 0.458 & 0.413 & 0.362 & 5.40 & 3.01 & 0.766 \\
Millet & $0.05 \pm$ & $0.54 \pm$ & $0.38 \pm$ & $-0.13 \pm$ & $1.65 \pm$ & $0.99 \pm$ \\
& 0.461 & 0.416 & 0.364 & 5.44 & 3.03 & 0.772 \\
Darawa & $-0.23 \pm$ & $0.58 \pm$ & $0.76 \pm$ & $0.41 \pm$ & $0.56 \pm$ & $0.94 \pm$ \\
& 0.470 & 0.424 & .371 & 5.54 & 3.09 & 0.787 \\
Family & $-0.02 \pm$ & $0.01 \pm$ & $0.01 \pm$ & $0.64 * \pm$ & 0.12 & $0.11^{* *} \pm 0.02$ \\
size & 0.021 & 0.019 & 0.017 & 0.258 & \pm 0.144 & \\
\hline$*$ ** : significance at $\mathrm{p}<05$ or $\mathrm{p}<0.01$, respectively. AU: Animal Unit, L = Local, C = Crossbred
\end{tabular}

Table 3. Percentage of different age classes (in years) from the respective species

\begin{tabular}{|c|c|c|c|c|c|c|}
\hline & \multicolumn{3}{|c|}{ Males } & \multicolumn{3}{|c|}{ Females } \\
\hline & $<1$ & $1-2$ & $>2$ & $<1$ & $1-2$ & $>2$ \\
\hline & \multicolumn{6}{|c|}{ Sheep } \\
\hline Mean & 24 & 2 & 6 & 15 & 12 & 42 \\
\hline Akhmim & 22 & 2 & 5 & 14 & 13 & 44 \\
\hline Jirjah & 24 & 2 & 6 & 14 & 10 & 43 \\
\hline \multirow[t]{2}{*}{ Sohag } & 25 & 3 & 6 & 15 & 13 & 38 \\
\hline & \multicolumn{6}{|c|}{ Goats } \\
\hline Mean & 30 & 1 & 6 & 17 & 9 & 38 \\
\hline Akhmim & 28 & 0 & 5 & 19 & 8 & 39 \\
\hline Jirjah & 32 & 1 & 6 & 13 & 6 & 43 \\
\hline Sohag & 30 & 2 & 6 & 16 & 11 & 34 \\
\hline
\end{tabular}

District had significant effect on all gender-age classes of sheep and goats (Table 4) except on males < $1 \mathrm{yr}$ and $>2 \mathrm{yr}$ in sheep and $>2 \mathrm{yr}$ for goats. Mean of males $<1 \mathrm{yr}$ was 3.58 heads in sheep which is more than 1.71 in goats as fattening is more 
common in lambs than kids. Fattening of lambs is mostly considered because they are easier to sell for cash to cater for different family needs. In general, there is no difference in means of males $>2 \mathrm{yr}$ in sheep and goats in the three studied districts. Number of lambs per household (Males < 1yr plus Females < 1yr) is 5.80 to 7.17 mature ewes in Akhmim, in Jirjah the figures are 5.52 lambs to 6.19 mature ewes, while in Sohag the ratio is 6.06 lambs to 5.73 mature ewes. Number of kids (Males $<1 \mathrm{yr}$ plus Females < 1yr) in Tables 4 and 5 is 3.29 kids to 2.74 does in Akhmim, 1.82 kids to 1.75 does in Jirjah and 2.85 kids to 2.04 does in Sohag. Thus, number of young per reproducing female in the flock/herd is $80 \%, 89 \%$ and $114 \%$ in Akhmim, Jirjah and Sohag, respectively, for sheep and 113\%, 104\% and 139\% in Akhmim, Jirjah and Sohag, respectively, for goats. These results indicate that, number of young per female in the flock/herd is higher in Sohag than Akhmim and Jirjah, indicating differences in management reflected in lambing/kidding rate and mortality; which was higher in goats than sheep.

Table 5 shows important independent variables $(\mathrm{P}<0.05)$ retained following forward stepwise regression analysis for the number of different livestock on various crop areas and family size. Only regression of buffalo and AU showed $R^{2}$ of $>0.40$ (ranges from $\mathrm{R}^{2}=0.01$ for goats to 0.44 for $\mathrm{AU}$ ). Generally, for large ruminants, farm size and area of darawa were retained for crossbreed cattle; area of berseem, wheat and millet for buffalo and area of berseem for local cattle. Farmers raising crossbred cattle used green fodder in both winter (berseem) and summer (darawa) while with an increases in buffalo numbers there is need for berseem and straw from wheat and millet. Local cattle are dependent on berseem $(P<0.05)$. Area of berseem and family size for $\mathrm{AU}$ indicate the importance of sheep to respond to the family needs. There is no logical explanation as why the only variable retained for goats is berseem with negative sign, i.e. the larger berseem area with less goat numbers.

Table 5. Significant partial regression coefficients retained in forward stepwise regression analysis for number of livestock on cropping pattern (area, feddan, F) and family size

\begin{tabular}{|c|c|c|c|c|c|c|}
\hline \multirow{2}{*}{$\begin{array}{l}\text { Independent } \\
\text { variables }\end{array}$} & \multicolumn{6}{|c|}{ Dependent variables } \\
\hline & Buffalo & L-cattle & C- cattle & Sheep & Goats & $\mathrm{AU}$ \\
\hline $\begin{array}{l}\text { Farm size } \\
(\mathrm{F}) .\end{array}$ & & & $0.11 \pm 0.02$ & & & \\
\hline Berseem (F) & $0.93 \pm 0.12$ & $0.84 \pm 0.08$ & & & $-1.33 \pm 0.56$ & $2.24 \pm 0.17$ \\
\hline Wheat $(\mathrm{F})$ & $0.19 \pm 0.06$ & & & & & \\
\hline $\begin{array}{l}\text { Faba bean } \\
\text { (F) }\end{array}$ & & & & & & \\
\hline Maize (F) & & & & & & \\
\hline $\begin{array}{l}\text { Sorghum } \\
\text { (F) }\end{array}$ & & & & & & \\
\hline Millet (F) & $0.29 \pm 0.09$ & & & & & \\
\hline Darawa (F) & & & $0.35 \pm 0.09$ & & & \\
\hline Family size & & & & $0.73 \pm 0.21$ & & $0.11 \pm 0.04$ \\
\hline $\mathrm{R}^{2}$ & 0.42 & 0.22 & 0.09 & 0.03 & 0.01 & 0.44 \\
\hline
\end{tabular}

$\mathrm{L}=$ Local,$\quad \mathrm{C}=$ Cross, $\mathrm{F}=$ Feddan . 


\section{CONCLUSIONS}

Sheep flock size among all assessed species, is highly associated with family size indicating Sohag farmers make use of family labor and maintain sheep as a source of capital for the family. Farmers raising buffaloes and/or crossbred cattle have increased their area of cultivated berseem and forage maize to increase productivity to meet demand of milk. This association does not prevail for small ruminants or local cattle.

\section{REFERENCES}

Alsheikh, S. M., A. Elnahas, Salah Galal, E. Mousa and M. Elshennawy (2011). Strategy options to improve gross margin in mixed crop-livestock farming system in Sohag governorate, Egypt. Egyptian J. Anim. Prod. 48 (2):147-156

Barnard, C.S. and J. S. Nix, 1993. Farm Planning and Control (2 ${ }^{\text {nd }}$ Ed.). Cambridge Press, Cambridge, UK.

Central Agricultural Statistics Administration. 2007. Livestock, Poultry and Fish Statistics for 2006. Vol 12, Ministry of Agriculture and Land Reclamation. 95 pp.

FAOSTAT. 2011. http://faostat.fao.org/ accessed on 20 June 2011.

Galal, S., Ferial Abdelrasoul, M. R. Anous and I. Shaat, 2005. Small Ruminant Breeds in Egypt. In Iniguez, Luis (ed.).2005. Characterization of Small Ruminant Breeds in West Asia and North Africa, Vol 2. North Africa, International Center for Agricultural Research in the Dry Areas (ICARDA), Alepp, Syria: 146-193.

ICLDU, 2006. Information Centers of Local Development Unit. Sohag governorate administration office, Sohag, Egypt.

Ministry of Agriculture and Agrarian Reform, Egypt and FAO. 2003. First Report on the State of Animal Genetic Resources in the Arab Republic of Egypt. Pp55.

SAS, 1989. User's guide. 6.12 ed. Statistical Analysis System Institute, Inc. Cary NC2755-8000, USA. 
العوامل المؤثرة على حيازات المجترات الصغيرة داخل منظومة مزارع المحاصيل- حيوانات

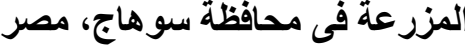

\author{
صلاح جلال ، احمد النحاس"، عماد موسى"، محمد الثناوى"، سمير الثيخْ
}

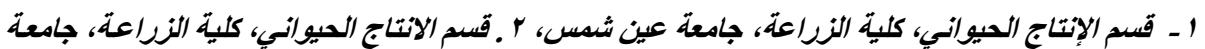

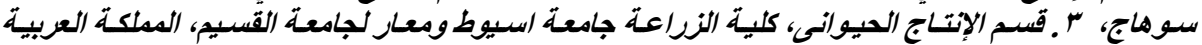

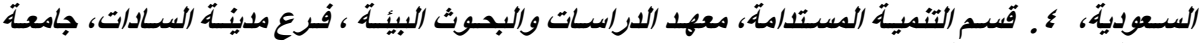

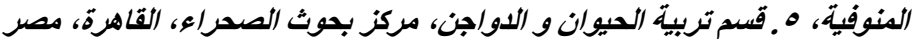

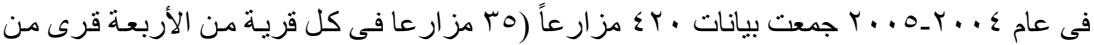

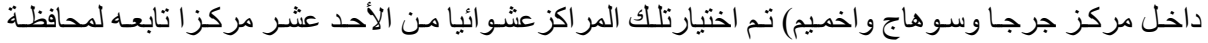

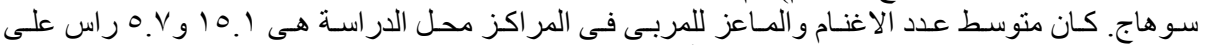

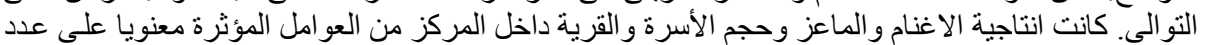

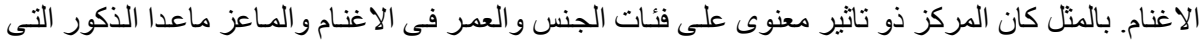

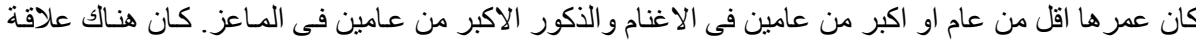

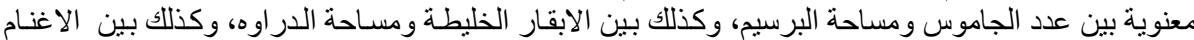

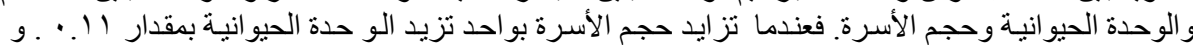

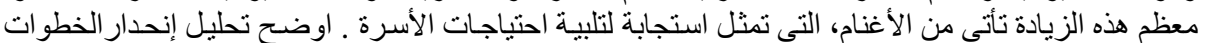

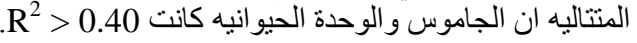


Table 4. Means of number of sheep and goats in different age (in years) classes

\begin{tabular}{|c|c|c|c|c|c|c|c|c|c|c|c|c|c|c|}
\hline \multirow{2}{*}{\multicolumn{2}{|c|}{ Item }} & \multirow[b]{2}{*}{ No. } & \multicolumn{6}{|c|}{ Sheep } & \multicolumn{6}{|c|}{ Goats } \\
\hline & & & \multicolumn{3}{|c|}{ Males } & \multicolumn{3}{|c|}{ Females } & \multicolumn{3}{|c|}{ Males } & \multicolumn{3}{|c|}{ Females } \\
\hline \multicolumn{2}{|c|}{ General mean } & 420 & 3.58 & 0.37 & 0.84 & 2.22 & 1.84 & 6.36 & 1.71 & 0.05 & 0.33 & 0.95 & 0.51 & 2.18 \\
\hline \multicolumn{2}{|c|}{ Akhmim } & 140 & $3.53^{\mathrm{a}}$ & $0.37^{\mathrm{a}}$ & $0.83^{\mathrm{a}}$ & $2.27^{\mathrm{a}}$ & $2.14^{\mathrm{a}}$ & $7.17^{\mathrm{a}}$ & $1.98^{\mathrm{a}}$ & $0.01^{\mathrm{a}}$ & $0.38^{\mathrm{a}}$ & $1.31^{\mathrm{a}}$ & $0.60^{\mathrm{a}}$ & $2.74^{\mathrm{a}}$ \\
\hline \multicolumn{2}{|c|}{ Jirjah } & 140 & $3.46^{\mathrm{a}}$ & $0.26^{\mathrm{b}}$ & $0.87^{\mathrm{a}}$ & $2.06^{\mathrm{b}}$ & $1.50^{\mathrm{b}}$ & $6.19^{\mathrm{b}}$ & $1.29^{\mathrm{b}}$ & $0.03^{\mathrm{a}}$ & $0.24^{\mathrm{a}}$ & $0.53^{\mathrm{c}}$ & $0.25^{\mathrm{b}}$ & $1.75^{\mathrm{b}}$ \\
\hline \multicolumn{2}{|l|}{ Sohag } & 140 & $3.74^{\mathrm{b}}$ & $0.48^{\mathrm{a}}$ & $0.83^{\mathrm{a}}$ & $2.32^{\mathrm{a}}$ & $1.89^{\mathrm{a}}$ & $5.73^{\mathrm{b}}$ & $1.85^{\mathrm{a}}$ & $0.12^{\mathrm{b}}$ & $0.37^{\mathrm{a}}$ & $1.00^{\mathrm{b}}$ & $0.70^{\mathrm{a}}$ & $2.04^{b}$ \\
\hline \multicolumn{2}{|c|}{ Village (D) } & & ** & $\mathrm{ns}$ & ns & ns & $* *$ & ** & ns & Ns & ns & ns & ns & $\mathrm{ns}$ \\
\hline & 3 & 35 & $3.66^{\mathrm{a}}$ & $0.34^{\mathrm{a}}$ & $0.82^{\mathrm{a}}$ & $2.43^{\mathrm{a}}$ & $1.89^{\mathrm{a}}$ & $8.16^{\mathrm{c}}$ & $1.78^{\mathrm{a}}$ & $0.04^{\mathrm{a}}$ & $0.22^{\mathrm{a}}$ & $1.27^{\mathrm{a}}$ & $0.21^{\mathrm{a}}$ & $2.16^{\mathrm{a}}$ \\
\hline & 4 & 35 & $4.15^{b}$ & $0.45^{\mathrm{a}}$ & $0.90^{\mathrm{a}}$ & $2.88^{\mathrm{a}}$ & $2.40^{\mathrm{b}}$ & $9.53^{\mathrm{c}}$ & $2.30^{\mathrm{a}}$ & $0.01^{\mathrm{a}}$ & $0.41^{\mathrm{a}}$ & $1.25^{\mathrm{a}}$ & $0.74^{\mathrm{a}}$ & $2.83^{\mathrm{a}}$ \\
\hline \multirow[t]{4}{*}{ Jirjah: } & 1 & 35 & $3.84^{\mathrm{a}}$ & $0.22^{\mathrm{a}}$ & $0.75^{\mathrm{a}}$ & $2.10^{\mathrm{a}}$ & $1.06^{\mathrm{c}}$ & $5.78^{\mathrm{a}}$ & $1.71^{\mathrm{a}}$ & $0.004^{\mathrm{a}}$ & $0.22^{\mathrm{a}}$ & $0.62^{\mathrm{a}}$ & $0.13^{\mathrm{a}}$ & $1.75^{\mathrm{a}}$ \\
\hline & 2 & 35 & $3.37^{\mathrm{a}}$ & $0.25^{\mathrm{a}}$ & $0.77^{\mathrm{a}}$ & $2.08^{a}$ & $1.05^{\mathrm{c}}$ & $5.68^{\mathrm{a}}$ & $1.64^{\mathrm{a}}$ & $0.02^{\mathrm{a}}$ & $0.14^{\mathrm{a}}$ & $0.41^{\mathrm{a}}$ & $0.09^{\mathrm{a}}$ & $1.49^{\mathrm{a}}$ \\
\hline & 3 & 35 & $3.16^{\mathrm{a}}$ & $0.26^{\mathrm{a}}$ & $1.01^{\mathrm{a}}$ & $1.93^{\mathrm{a}}$ & $1.78^{\mathrm{a}}$ & $6.56^{\mathrm{b}}$ & $0.99^{\mathrm{a}}$ & $0.05^{\mathrm{a}}$ & $0.31^{\mathrm{a}}$ & $0.44^{\mathrm{a}}$ & $0.46^{\mathrm{a}}$ & $1.84^{\mathrm{a}}$ \\
\hline & 4 & 35 & $3.46^{\mathrm{a}}$ & $0.30^{\mathrm{a}}$ & $0.96^{\mathrm{a}}$ & $2.15^{\mathrm{a}}$ & $2.11^{\mathrm{a}}$ & $6.73^{\mathrm{b}}$ & $0.82^{\mathrm{a}}$ & $0.05^{\mathrm{a}}$ & $0.28^{\mathrm{a}}$ & $0.63^{\mathrm{a}}$ & $0.32^{\mathrm{a}}$ & $1.90^{\mathrm{a}}$ \\
\hline
\end{tabular}

Issued by The Egyptian Society of Animal Production 
Within classifications means with the same letters are not significantly different $(\mathrm{P}<0.05)$.

ns, * **: $\mathrm{p} \geq 0.05, \mathrm{p}<0.05, \mathrm{p} \leq 0.01$, respectively, for the classification as a source of variation

Sheep: standard error for general mean for male < $1 \mathrm{yr}, 1-2 \mathrm{yr}$ and $>2 \mathrm{yr} 0.099,0.031$ and 0.018 for district means $0.238,0.066$ and 0.044 and for village means: $0.343,0.109$ and 0.065 respectively. While, for Female $<1 \mathrm{yr},(1-2) \mathrm{yr}$ and $>2 \mathrm{yr} 0.083,0.078$ and 0.216 , for district means, $0.173,0.276$ and 0.812 , and for village means: 0.173 , 0.270 and 0.751 , respectively.

Goats: stand Goats: 076 , respe While, for Female $<1$ yr, (1-2) yr and $>2 \mathrm{yr} 0.058,0.048$ and 0.099 for district means, $0.103,0.120$ and 0.232 and for village means: $0.204,0.165$ and 0.345 , respectively. 